\section{The Italian Earthquake of July 23.}

YINCE Jan. 13, 1915, when Avezzano and other towns in central Italy were ruined, there has been no earthquake in the peninsula so destructivo as that which visited the provinces of the Basilicata and Campania shortly after 1 A.M. (0 A.M. Greenwich mean time) on July 23 . The latest estimate of the number of persons killed is 1883, while the buildings of 34 communes are said to have been seriously damaged. The epicentre, which seems to be close to the town of Lacedonia, lies about 65 miles slightly north of east from Naples.

The aroa of slight damage, as at present known, is bounded by a curve that is roughly in the form of an ellipse directed west-north-west, 39 miles long, 16 miles wide, and containing about 490 square miles. The places that have suffered most are Villanova, Aquilonia, and Lacedonia, lying within a district about 19 miles long and 90 square miles in area, in the north-west half of the formor curve, and Melfi and the surrounding towns near its south-east end. The principal centre apparently lies midway between Villanova and Lacedonia, but there may have been a secondary centre close to Melfi about 20 miles to the east-south-east. The shock was strong enough to damage a few houses in Naples and to have boon felt in the province of the Marches, and even so far as Rome, so that the total area disturbed may contain about 95,000 square miles, or roughly that of the Hereford earthquake of 1896 . The first movements were recorded at Kew at $0 \mathrm{~h} .12 \mathrm{~m} .11 \mathrm{~s}$. and at Helwan (Egypt) at 0 h. $12 \mathrm{~m} .42 \mathrm{~s}$.

The province of the Basilicata is one of the most unstable regions in Italy. The great Neapolitan earthquake of Doc. 16, 1857, so admirably investigated by Robert Mallet, disturbed chiefly the southern part of the province. Mallet, from observations on the direction of the shock, placed the epicentre near the village of Caggiano, which lies about 34 miles to the south of that of the recent earthquake, but the principal centre was probably near Montomurro, 24 miles south-east of Caggiano. More closoly connected with the recent earthquake are the Avollino earthquake of Sept. 8, 1694, and the Melfi earthquake of Aug. 14, 1851, described by Dr. Mario Baratta in his valuable work "I terremoti d' Italia" (pp. 173$181,407-410 ; 1901)$. In 1694 , the number of persons killed was 3571 . The area of destruction was of unusual size, extending about 50 miles north-west from Potenza. In 1851,628 persons lost their lives, and the moizoseismal area was small, not more than 11 miles in length, with its centre close to Molfi. The area strongly shaken by the recent earthquake thus includes that of the Melfi earthquake and lies along the northern boundary of that of the earthquake of 1694 .

C. Davison.

\section{The Skull of Peking Man.}

$\mathrm{D}$ R. DAVIDSON BLACK'S interim report on the skull of Sinanthropus found at Chou Kou 'Tien at the end of last year was presented at a sossion of the annual mooting of the Geological Society of China held on Mar. 29 last, and has now been published in the Bulletin of the Society. It is illustrated by six plates which reproduce the natural size of the photographs of the frontal, right and left laterals, occipital, vertical and basal views of tho skull.

The whole external surface has now been freed from travertine, with which, however, the interior is still filled. During the preparation of the skull, the major parts of parietals and the whole of the frontal bone were separated from the stone filling; but these wore replaced for the purpose of the photographs, which show the parts in approximately correct relation. A table of measurements is given which supploments and corrects those of the previous report, but they are themselves only approximate and subject to correction.

The skull, doubtfully idontified as fernale, has a glabello-occipital length of $192 \mathrm{~mm}$. and a breadth of $132 \mathrm{~mm}$. (?), the maximum breadth which falls between the supra-mastoid regions of the tomporal bones being circa $144 \mathrm{~mm}$. The loast frontal broadth is $83 \mathrm{~mm}$. (?) and the groatest frontal breadth $102 \mathrm{~mm}$. (?). The auricular height is $97 \mathrm{~mm}$. (?) The parietal eminences are quite well devoloped; but the sides of the cranial vault below them are markedly inclined toward one another. The bones are much thicker in certain regions than was supposed (for example, below the lambda). They do not show the excessive thicknoss of the Piltdown skull, but they are much thicker than in modern man.

One of the most, if not the most interesting point brought out by Dr. Black in this interim report is the bearing of certain unique morphological features which were not apparent at the carlier stages of preparation. It is now clear that what was previously considered to be a markedly developed post-glenoid process is seen to be a very poculiarly developed tympanic portion of the temporal. In the massive parts of the tympanic elements, the posterior moiety is developed to form a prominent crest which extends inward to the base of the minute styloid process, while the anterior portion of the tympanic bone forms a massive rounded wall limiting the mandibular fossa and rising abruptly immediately behind the petro-tympanic fissure. The glenoid cavities are thus obliquely placed deep fossæ, the visible floors of which are formed wholly from the zygomatic elements of the temporal bones. The mandibular fossw are thus wholly hominid in character.

It is, however, extremely interesting to. note that for the first time among hominids is found a stage of development much more archaic than in Neanderthal man and at the same time in certain features recalling some of the relations characterising this region in anthropoids, such, for example, as the chimpanzee. Dr. Black recalls that both Boule and Martin in referenco to the La Chapelle and La Quina skulls respectively have pointed to certain resemblances to the chimpanzee in that region, placing them somewhat intermediately in type between that form and Homo. The Peking skull in this respoct may be termed pre-Noanderthaloid, and in the hominid scale may be not far removed from the type which evolved both the extinct Neanderthal and the modern Homo sapiens.

\section{University and Educational Intelligence.}

LEEDs.-The Council of the University of Loeds has elected Dr. F. Challenger to the chair of organic chemistry shortly to be vacated by Prof. C. K. Ingold. Dr. Challenger, who is at present senior lecturer in chemistry at the University of Manchester, is a graduate of London and Göttingon. Throughout his career he has been actively engaged on research work; amongst the subjects to which he has given attention are the organo-derivatives of bismuth, the organic chemistry of sulphur and the technology of mineral oils, the production of acids such as eitric and oxalic by biological processes, and the chemistry of petroloum.

Manchester.-Applications are invited for the Amy Honrietta Worswick followship for the investigation of the causes and treatment of rheumatoid 